\title{
Distribution of Chlamydia trachomatis genovars among youths and adults in Brazil
}

\author{
Ana C. S. Machado, ${ }^{1}$ Claudiu I. Bandea, ${ }^{2}$ Maria F. C. Alves, ${ }^{1}$ \\ Kahaliah Joseph, ${ }^{2}$ Joseph Igietseme, ${ }^{2}$ Angélica E. Miranda, ${ }^{3}$ \\ Eleuse M. B. Guimarães, ${ }^{4}$ Marília D. Turchi ${ }^{5}$ and Carolyn M. Black ${ }^{2}$ \\ ${ }^{1}$ Department of Microbiology, Immunology, Parasitology and Pathology, Institute of Tropical \\ Pathology and Public Health, Federal University of Goiás, Brazil \\ ${ }^{2}$ Division of Scientific Resources, Centers for Disease Control and Prevention, Atlanta, GA, USA \\ ${ }^{3}$ Nucleus of Infectious Diseases, Federal University of Espírito Santo, Vitória, Brazil \\ ${ }^{4}$ Division of Adolescent Medicine, Department of Pediatrics, Faculty of Medicine, Federal University \\ of Goiás, Brazil \\ ${ }^{5}$ Department of Community Health, Institute of Tropical Pathology and Public Health, Federal \\ University of Goiás, Brazil
}

Correspondence

Maria F. C. Alves

fc-alves@hotmail.com

Received 24 September 2010 Accepted 22 December 2010

\begin{abstract}
Despite a high prevalence of sexually transmitted Chlamydia trachomatis infections in Brazil and other countries in South America, very little is known about the distribution of C. trachomatis genovars. In this study, we genotyped C. trachomatis strains from urine or endocervical specimens collected from 163 C. trachomatis-positive female and male youths, and female adults, residing in two different regions of Brazil, the city of Goiânia located in the central part of Brazil, and the city of Vitória in the south-east region. C. trachomatis strains were genotyped by amplifying and sequencing the ompA gene encoding the chlamydial major outer-membrane protein, which is genovar specific. We found nine different $C$. trachomatis genovars: $\mathrm{E}(39.3 \%), \mathrm{F}$ (16.6\%), D (15.9\%), I (8.6\%), J (7.4\%), G (4.9\%), K (3.1\%), H (2.4\%) and B (1.8\%). The distribution of the $C$. trachomatis genovars in the two regions of Brazil was similar, and there was no statistically significant association of serovars with age, gender, number of sexual partners or clinical symptoms. The overall distribution of C. trachomatis genovars in Brazil appears similar to that found in other regions of the world, where E, D and F are the most common. This supports the notion that, during the last few decades, the overall distribution of C. trachomatis genovars throughout the world has been relatively stable.
\end{abstract}

\section{INTRODUCTION}

Chlamydia trachomatis urogenital infection is the primary cause of bacterial sexually transmitted diseases (STDs) in the world (WHO, 2001). In Brazil, several studies using highly sensitive diagnostic tests based on nucleic acid amplification technology have showed a prevalence of $C$. trachomatis infections ranging from 5.0 to $19.6 \%$ among youths attending outpatient clinics and gynaecological clinics, and taking part in the Family Health programme (Guimarães et al., 2009; Araújo et al., 2006; Fioravante et al., 2005; Miranda et al., 2004).

Using polyvalent mouse antiserum, $C$. trachomatis isolates historically have been classified into 14 major serovars, A to $\mathrm{K}$ and L1, L2 and L3 (Wang et al., 1973). Urogenital tract infections are usually caused by serovars D to K. After it was discovered that serovar specificity resides in the major

Abbreviation: STD, sexually transmitted disease. outer-membrane protein (MOMP) (Caldwell et al., 1981), immunotyping approaches were replaced by genotyping methods that identify genovar-specific DNA sequence variation markers within the MOMP-encoding gene, ompA (referred to in some publications as omp1) (Stothard et al., 1998; Yuan et al., 1989; Stephens et al., 1987). New genotyping approaches have recently been developed, such as multilocus variable number tandem repeat and multilocus sequence typing analyses, that increase the epidemiological resolution among the various C. trachomatis strains (Pedersen et al., 2008; Klint et al., 2007). However, these approaches have been used within the framework of the current ompA-based C. trachomatis classification system as there is not yet a standardized nomenclature or classification system based on these novel typing methods (Pedersen et al., 2009).

Although the distribution of C. trachomatis genovars in some regions of the world is well known (Taheri Beni et al., 
2010; Petrovay et al., 2009; Bandea et al., 2008; Millman et al., 2004; Ngandjio et al., 2003; Jurstrand et al., 2001; Bandea et al., 2001), there is only one published study from Brazil, which reported the distribution of $C$. trachomatis genovars among a small group of nine women attending an STD clinic in the south-east region (Lima et al., 2007). The aims of the present study were to investigate the distribution of $C$. trachomatis genovars in a larger population and their potential associations with socio-demographic characteristics and clinical symptoms.

\section{METHODS}

Study population and data collection. The specimen collection, demographic, and sexual and behavioural characteristics of patients included in this study have been described previously (Guimarães et al., 2009; Barcelos et al., 2008; Araújo et al., 2006; Fioravante et al., 2005; Miranda et al., 2004). A summary of these studies is outlined in Table 1 . The participants in the study were female and male youths (age range 14-24 years old) and female adults (age range 25-49 years old) residing in Goiânia, in the central region of Brazil, and in Vitória, a city in the south-east region. Most participants were recruited from public health services, except for the male conscripts. The biological samples were collected between 2000 and 2004, and screened for C. trachomatis using commercial nucleic acids amplification tests. A total of 187 C. trachomatis-positive samples (first catch urine, 82; endocervical swab, 105) were shipped on dry ice to the Centers for Disease Control and Prevention in Atlanta, where they were genotyped. The protocol for this study was approved by the Ethics Committee at the University Hospital, Federal University of Goiás, and the National Council of Research in Brazil, and by the Institutional Review Board of the Centers for Disease Control and Prevention.

C. trachomatis genotyping. C. trachomatis genotyping was performed as previously described (Bandea et al., 2001), using the PCR and sequencing primers shown in Table 2. To determine the $C$. trachomatis genovars we used the neighbour-joining phylogenetic program provided in the GeneStudio package (GeneStudio Inc.).

Statistical analysis. Statistical analysis was performed using SPSS 15.0. Association of chlamydial genovars to demographic and behavioural characteristics was assessed with the $\chi^{2}$ test or Fisher exact test. Statistical significance was established as $P<0.05$.

\section{RESULTS AND DISCUSSION}

This is believed to be the first large molecular epidemiological study on the distribution of urogenital $C$. trachomatis genovars in Brazil, and their association with age, gender, number of sexual partners and clinical symptoms. From the total of 187 specimens positive for C. trachomatis by PCR or LCR (ligase chain reaction) included in this study, we were able to amplify and sequence the ompA gene from $163(87 \%)$ specimens, 91 from endocervical specimens and 72 from urine specimens. Despite at least two amplification attempts with each of two nested primer sets used in the study protocol (Table 2), we were not able to amplify the ompA gene from 24 (13\%) specimens. There are several potential reasons for the apparent lower sensitivity of our in-house amplification assays. Possibly, some of the initial diagnostic results were false positives. Another potential explanation is that the target for the commercial diagnostic tests was a multi-copy plasmid (Mahony et al., 1993), whereas the ompA gene, which was the target of our assay, is only present at one copy per organism.

We found nine different genovars in our study population: E (39.3\%), F (16.6\%), D (15.9\%), I (8.6\%), J (7.4\%), G $(4.9 \%), \mathrm{K}(3.1 \%), \mathrm{H}(2.4 \%)$ and $\mathrm{B}(1.8 \%)$. In the municipality of Goiânia genovar $\mathrm{E}$ was the most frequent (36.3\%), followed by genotype D (19.5\%) and F (16.8\%). In Vitória, genovar $\mathrm{E}$ also showed higher prevalence $(46.0 \%)$ followed by genovar F $(16.0 \%)$ and I (10.0\%). Interestingly, three participants from our study population were infected with genovar B, which is usually associated with ocular C. trachomatis infections; however, there have been similar reports of ocular genovars found in the urogenital tract (Millman et al., 2004; Darville, 2005).

The only published genotyping study from Brazil was that reported by Lima et al. (2007) in which four different $C$. trachomatis genovars (E, D, F and $\mathrm{K}$ ) were identified among a small group of nine infected female patients between the ages of 15 and 54 attending an STD clinic in south-eastern Brazil. The most prevalent C. trachomatis genovars in our Brazilian study population were E, F and D. In Costa Rica, among 806 C. trachomatis-positive samples obtained from young women, E $(31 \%)$ was the most common genovar, followed by F (21\%) and D $(21 \%)$ (Quint et al., 2007). Also, E was the most frequent genovar in the metropolitan area of Buenos Aires, Argentina, where 199 samples positive for C. trachomatis infection were genotyped from a population of symptomatic adults and neonates (Gallo Vaulet et al., 2010).

Table 1. Positive C. trachomatis subjects and specimen types $(n=187)$

\begin{tabular}{|c|c|c|c|c|}
\hline Study & Study population & Specimen & Collection period & $\begin{array}{c}\text { No. of } \\
\text { samples }\end{array}$ \\
\hline Guimarães et al. (2009) & Female youths $(n=427)$ & Endocervical swab & July 2003 to January 2004 & 58 \\
\hline Araújo et al. (2006) & Female youths $(n=296)$ & Endocervical swab & March 2000 to March 2001 & 47 \\
\hline Fioravante et al. (2005) & Male youths - military conscripts $(n=654)$ & Urine & September to October 2000 & 26 \\
\hline Miranda et al. (2004) & Female youths $(n=461)$ & Urine & March to June 2003 & 34 \\
\hline
\end{tabular}


Table 2. C. trachomatis primers for $o m p A$ amplification and sequencing

\begin{tabular}{|c|c|}
\hline Name & Sequence \\
\hline \multicolumn{2}{|c|}{ Primary PCR primers } \\
\hline CT90UF & 5'-GGACATCTTGTCTGGCTTTAACT-3' \\
\hline T220DR & 5'-GCGCTCAAGTAGACCGATATAGTA-3' \\
\hline CT662UF & 5'-AGCTTAGGAGCTTCTTTCCAATA-3' \\
\hline CT1180DR & 5'-CGGAATTGTGCATTTACGTGAG-3' \\
\hline \multicolumn{2}{|c|}{ Secondary PCR primers } \\
\hline CT60UF & 5'-GTCCCGCCAGAAAAAGATAG-3' \\
\hline T80DR & 5'-CCAGAAACACGGATAGTGTTATTA-3' \\
\hline CT725UF & 5'-TCTCTGTAATGCATCCGAATTTACTAT-3' \\
\hline CT1086DR & 5'-TCGAATACCGCAAGATTTTCT-3' \\
\hline \multicolumn{2}{|c|}{ Sequencing primers } \\
\hline CT40F & 5'-ATAGCGAGCACAAAGAGAGC-3' \\
\hline CT419F & 5'-TGGGATCGTTTTGATGTATT-3' \\
\hline CT902F & 5'-TCCTTACATTGGAGTTAAATGGTC-3' \\
\hline CT725F & $5^{\prime}$-TCTCTGTAATGCATCCGAATTTACTAT-3' \\
\hline CT1086R & 5'-TCGAATACCGCAAGATTTTCT-3' \\
\hline
\end{tabular}

Most studies from other regions of the world found a similar distribution of $C$. trachomatis genovars. For example, in a study performed in Sweden with 237 urogenital samples, the most prevalent genotype was $\mathrm{E}$ (47.3\%), followed by F (17.3\%) (Jurstrand et al., 2001). In a larger study $(n=678)$ from the same country, the most

Table 3. Distribution of C. trachomatis genovars according to socio-demographic characteristics and clinical symptoms

A $\chi^{2}$ test with three degrees of freedom was applied to compare the relative frequency of four groups (genotypes D, E, F and others) versus sociodemographic characteristics and clinical symptoms. Age group: $\chi^{2}=1.88, P=0.59$; gender: $\chi^{2}=4.34, P=0.23$; city: $\chi^{2}=3.79, P=0.28$; specimens: $\chi^{2}=7.65, P=0.05$; lifetime sexual partners: $\chi^{2}=4.39, P=0.22$; symptoms: $\chi^{2}=5.52, P=0.13$.

\begin{tabular}{|c|c|c|c|c|c|c|c|c|c|c|}
\hline \multirow{2}{*}{$\begin{array}{l}\text { Characteristics of } \\
\text { patients }\end{array}$} & \multirow{2}{*}{$\begin{array}{c}\text { No. of } \\
\text { samples }\end{array}$} & \multicolumn{9}{|c|}{ No. of isolates of each genotype (\%) } \\
\hline & & B & $\mathbf{D}$ & $\mathbf{E}$ & $\mathbf{F}$ & G & $\mathbf{H}$ & $\mathbf{I}$ & $\mathbf{J}$ & $\mathbf{K}$ \\
\hline \multicolumn{11}{|l|}{ Age $^{*}$} \\
\hline $14-19$ years & 133 & $3(2.2)$ & $23(17.3)$ & $52(39.1)$ & $23(17.3)$ & $4(3.0)$ & $4(3.0)$ & $13(9.8)$ & $8(6.0)$ & $3(2.2)$ \\
\hline$\geqslant 20$ years & 25 & 0 & $2(8.0)$ & $10(40.0)$ & $4(16.0)$ & $2(8.0)$ & 0 & $1(4.0)$ & $4(16.0)$ & $2(8.0)$ \\
\hline \multicolumn{11}{|l|}{ Gender } \\
\hline Female & 141 & $3(2.1)$ & $24(17.0)$ & $56(39.7)$ & $25(17.7)$ & $3(2.1)$ & $4(2.8)$ & $12(8.5)$ & $9(6.4)$ & $5(3.5)$ \\
\hline Male & 22 & 0 & $2(9.1)$ & $8(36.4)$ & $2(9.1)$ & $5(22.7)$ & 0 & $2(9.1)$ & $3(13.6)$ & 0 \\
\hline \multicolumn{11}{|l|}{ City } \\
\hline Goiânia & 113 & $2(1.8)$ & $22(19.5)$ & $41(36.3)$ & $19(16.8)$ & $7(6.2)$ & $3(2.7)$ & $9(8.0)$ & $9(8.0)$ & $1(0.9)$ \\
\hline Vitória & 50 & $1(2.0)$ & $4(8.0)$ & $23(46.0)$ & $8(16.0)$ & $1(2.0)$ & $1(2.0)$ & $5(10.0)$ & $3(6.0)$ & $4(8.0)$ \\
\hline \multicolumn{11}{|l|}{ Specimen } \\
\hline Endocervical swab & 91 & $2(2.2)$ & $20(22.0)$ & $33(36.3)$ & $17(18.7)$ & $2(2.2)$ & $3(3.3)$ & $7(7.7)$ & $6(6.6)$ & $1(1.1)$ \\
\hline Urine & 72 & $1(1.4)$ & $6(8.3)$ & $31(43.0)$ & $10(13.9)$ & $6(8.3)$ & $1(1.4)$ & $7(9.7)$ & $6(8.3)$ & $4(5.5)$ \\
\hline \multicolumn{11}{|l|}{$\begin{array}{l}\text { No. of sexual } \\
\text { partners in life } \dagger\end{array}$} \\
\hline $1-3$ & 94 & $1(1.1)$ & $17(18.1)$ & $38(40.4)$ & $18(19.1)$ & $2(2.1)$ & $1(1.1)$ & $10(10.6)$ & $5(5.3)$ & $2(2.1)$ \\
\hline$\geqslant 4$ & 63 & $2(3.2)$ & $8(12.7)$ & $24(38.1)$ & $8(12.7)$ & $4(6.3)$ & $3(4.8)$ & $4(6.3)$ & $7(11.1)$ & $3(4.8)$ \\
\hline \multicolumn{11}{|l|}{ Symptoms $\ddagger$} \\
\hline Yes & 94 & $2(2.1)$ & $17(18.1)$ & $36(38.3)$ & $20(21.3)$ & $2(2.1)$ & 0 & $8(8.5)$ & $6(6.4)$ & $3(3.2)$ \\
\hline No & 63 & $1(1.6)$ & $7(11.1)$ & $28(44.4)$ & $7(11.1)$ & $4(6.3)$ & $4(6.3)$ & $5(7.9)$ & $5(7.9)$ & $2(3.2)$ \\
\hline
\end{tabular}

* There were five participants without this information. $\dagger$ There were five participants without this information. $\ddagger$ There were six participants without this information. 
frequent genovar was E (39\%), followed by F (21\%), G ( $11 \%), \mathrm{D}$ and $\mathrm{K}$ (both $9 \%), \mathrm{J}(7 \%), \mathrm{H}(2 \%)$, and B and Ia (both 1\%) (Lysén et al., 2004). A study conducted in Iceland in a population attending an STD clinic $(n=330)$ found, in descending order of prevalence, genovars E, D, J, F, K, G, H and I (Jónsdóttir et al., 2003). Among 203 urine samples collected in Australia, the E serovar was also the most prevalent $(42.4 \%)$, followed by $\mathrm{F}(23.6 \%)$ and $\mathrm{G}$ (16.3\%) (Mossman et al., 2008); and among 102 samples of endocervical swabs or urine from patients visiting two hospitals in Taiwan, genotype $\mathrm{E}$ was the most prevalent (22\%), followed by D (19\%), F (16\%) and J (15\%) (Hsu et al., 2006). However, in a study in Thailand, the prevalence of C. trachomatis genovar E was only $9.3 \%$, with F (25\%) being the most prevalent (Bandea et al., 2001); and in Hungary, a study conducted among 484 female sex workers identified genotype $\mathrm{D}$ as the most prevalent $(34.4 \%)$, followed by $\mathrm{E}(21.9 \%)$ and $\mathrm{F}(18.8 \%)$ (Petrovay et al., 2009).

Table 3 shows the distribution of $C$. trachomatis genovars according to socio-demographic and clinical symptoms. The distribution $C$. trachomatis genovars was similar among the age groups, and between men and women, and there was no statistically significant association of the C. trachomatis genovars with the number of lifetime sexual partners, or with clinical symptoms such as lower abdominal pain, vaginal/urethral discharge or dysuria; however, these comparisons are limited by the low numbers of positives samples in some subgroups and the large diversity of genotypes identified.

The potential association of $C$. trachomatis genovars with specific clinical symptoms, or disease, is not well understood. Van Duynhoven et al. (1998) found an association of genovars $\mathrm{H}$ and $\mathrm{J}$ with urethral discharge and dysuria in men, and an association of genovars $F$ and $G$ with lower abdominal pain in women. A study by Van de Laar et al. (1996) indicated that genovars F and G cause milder symptoms and signs of inflammation in men but not in women. Another study conducted by Gao et al. (2007) reported an association between genotype $G$ and lower abdominal pain. After controlling for age and race, Geisler et al. (2003) found that women who reported abdominal pain and/or dyspareunia were more likely to be infected with genovar F. An association of specific clinical manifestations with genovars was not detected in men. In a study performed with females from an STD high-risk population in Senegal, Sturm-Ramirez et al. (2000) reported that there were no visible signs of cervical inflammation in females infected with genovar E compared with those infected with other $C$. trachomatis genovars. Similarly, several other studies have found no statistically significant difference in the distribution of $C$. trachomatis genovars between patients with symptomatic or asymptomatic infections (Lysén et al., 2004; Persson \& Osser, 1993; Millman et al., 2004; Batteiger et al., 1989). Hopefully, the new genotyping methods, such as multilocus variable number tandem repeat and multilocus sequence typing, will lead to a new classification system for $C$. trachomatis strains and to improved algorithms for studying their association with pathological and clinical outcomes (Pedersen et al., 2008, 2009; Klint et al., 2007).

In conclusion, we found that the overall distribution of $C$. trachomatis genovars in Brazil, where E, F and D are the most common genovars, is similar to that found in other regions of the world. This supports the notion that, during the last few decades, the circulation and the overall distribution of $C$. trachomatis genovars throughout the world have been relatively stable.

\section{ACKNOWLEDGEMENTS}

A. C. S. M. was supported by a scholarship from the National Council of Technological and Scientific Development (CNPq), Brazil (project number 141821/2006-0). We thank Y. A. R. Lima for technical assistance.

\section{REFERENCES}

Araújo, R. S., Guimarães, E. M., Alves, M. F., Sakurai, E., Domingos, L. T., Fioravante, F. C. \& Machado, A. C. (2006). Prevalence and risk factors for Chlamydia trachomatis infection in adolescent females and young women in central Brazil. Eur J Clin Microbiol Infect Dis 25, 397-400.

Bandea, C. I., Kubota, K., Brown, T. M., Kilmarx, P. H., Bhullar, V., Yanpaisarn, S., Chaisilwattana, P., Siriwasin, W. \& Black, C. M. (2001). Typing of Chlamydia trachomatis strains from urine samples by amplification and sequencing the major outer membrane protein gene (omp1). Sex Transm Infect 77, 419-422.

Bandea, C. I., Debattista, J., Joseph, K., Igietseme, J., Timms, P. \& Black, C. M. (2008). Chlamydia trachomatis serovars among strains isolated from members of rural indigenous communities and urban populations in Australia. J Clin Microbiol 46, 355-356.

Barcelos, M. R., Vargas, P. R., Baroni, C. \& Miranda, A. E. (2008). Genital infections in women attending a primary unit of health: prevalence and risk behaviors. Rev Bras Ginecol Obstet 30, 349354.

Batteiger, B. E., Lennington, W., Newhall, W. J., Katz, B. P., Morrison, H. T. \& Jones, R. B. (1989). Correlation of infecting serovar and local inflammation in genital chlamydial infections. J Infect Dis 160, 332336.

Caldwell, H. D., Kromhout, J. \& Schachter, J. (1981). Purification and partial characterization of the major outer membrane protein of Chlamydia trachomatis. Infect Immun 31, 1161-1176.

Darville, T. (2005). Chlamydia trachomatis infections in neonates and young children. Semin Pediatr Infect Dis 16, 235-244.

Fioravante, F. C., Costa Alves, M. F., Guimarães, E. M., Turchi, M. D., Freitas, H. A. \& Domingos, L. T. (2005). Prevalence of Chlamydia trachomatis in asymptomatic Brazilian military conscripts. Sex Transm Dis 32, 165-169.

Gallo Vaulet, L., Entrocassi, C., Corominas, A. I. \& Rodríguez Fermepin, M. (2010). Distribution study of Chlamydia trachomatis genotypes in symptomatic patients in Buenos Aires, Argentina: association between genotype $\mathrm{E}$ and neonatal conjunctivitis. BMC Res Notes 3, 34.

Gao, X., Chen, X. S., Yin, Y. P., Zhong, M. Y., Shi, M. Q., Wei, W. H., Chen, Q., Peeling, R. W. \& Mabey, D. (2007). Distribution study of Chlamydia 
trachomatis serovars among high-risk women in China performed using PCR-restriction fragment length polymorphism genotyping. J Clin Microbiol 45, 1185-1189.

Geisler, W. M., Suchland, R. J., Whittington, W. L. H. \& Stamm, W. E. (2003). The relationship of serovar to clinical manifestations of urogenital Chlamydia trachomatis infection. Sex Transm Dis 30, 160-165.

Guimarães, E. M., Guimarães, M. D., Vieira, M. A., Bontempo, N. M., Seixas, M. S., Garcia, M. S., Daud, L. E., Côrtes, R. L. \& Alves, M. F. (2009). Lack of utility of risk score and gynecological examination for screening for sexually transmitted infections in sexually active adolescents. BMC Med 7, 8 .

Hsu, M. C., Tsai, P. Y., Chen, K. T., Li, L. H., Chiang, C. C., Tsai, J. J., Ke, L. Y., Chen, H. Y. \& Li, S. Y. (2006). Genotyping of Chlamydia trachomatis from clinical specimens in Taiwan. J Med Microbiol 55, 301-308.

Jónsdóttir, K., Kristjánsson, M., Hjaltalín Olafsson, J. \& Steingrimsson, O. (2003). The molecular epidemiology of genital Chlamydia trachomatis in the greater Reykjavik area, Iceland. Sex Transm Dis 30, 249-256.

Jurstrand, M., Falk, L., Fredlund, H., Lindberg, M., Olcén, P., Andersson, S., Persson, K., Albert, J. \& Bäckman, A. (2001). Characterization of Chlamydia trachomatis omp1 genotypes among sexually transmitted disease patients in Sweden. J Clin Microbiol 39, 3915-3919.

Klint, M., Fuxelius, H. H., Goldkuhl, R. R., Skarin, H., Rutemark, C., Andersson, S. G., Persson, K. \& Herrmann, B. (2007). Highresolution genotyping of Chlamydia trachomatis strains by multilocus sequence analysis. J Clin Microbiol 45, 1410-1414.

Lima, H. E., Oliveira, M. B., Valente, B. G., Afonso, D. A., Darocha, W. D., Souza, M. C., Alvim, T. C., Barbosa-Stancioli, E. F. \& Noronha, F. S. (2007). Genotyping of Chlamydia trachomatis from endocervical specimens in Brazil. Sex Transm Dis 34, 709-717.

Lysén, M., Österlund, A., Rubin, C. J., Persson, T., Persson, I. \& Herrmann, B. (2004). Characterization of ompA genotypes by sequence analysis of DNA from all detected cases of Chlamydia trachomatis infections during 1 year of contact tracing in a Swedish county. J Clin Microbiol 42, 1641-1647.

Mahony, J. B., Luinstra, K. E., Sellors, J. W. \& Chernesky, M. A. (1993). Comparison of plasmid- and chromosome-based polymerase chain reaction assays for detecting Chlamydia trachomatis nucleic acids. J Clin Microbiol 31, 1753-1758.

Millman, K., Black, C. M., Johnson, R. E., Stamm, W. E., Jones, R. B., Hook, E. W., Martin, D. H., Bolan, G., Tavaré, S. \& Dean, D. (2004). Population-based genetic and evolutionary analysis of Chlamydia trachomatis urogenital strain variation in the United States. J Bacteriol 186, 2457-2465.

Miranda, A. E., Szwarcwald, C. L., Peres, R. L. \& Page-Shafer, K. (2004). Prevalence and risk behaviors for chlamydial infection in a population-based study of female adolescents in Brazil. Sex Transm Dis 31, 542-546.

Mossman, D., Beagley, K. W., Landay, A. L., Loewenthal, M., Ooi, C., Timms, P. \& Boyle, M. (2008). Genotyping of urogenital Chlamydia trachomatis in regional New South Wales, Australia. Sex Transm Dis 35, 614-616.

Ngandjio, A., Clerc, M., Fonkoua, M. C., Thonnon, J., Njock, F., Pouillot, R., Lunel, F., Bebear, C., De Barbeyrac, B. \& Bianchi, A. (2003). Screening of volunteer students in Yaounde (Cameroon,
Central Africa) for Chlamydia trachomatis infection and genotyping of isolated C. trachomatis strains. J Clin Microbiol 41, 4404-4407.

Pedersen, L. N., Pødenphant, L. \& Møller, J. K. (2008). Highly discriminative genotyping of Chlamydia trachomatis using omp1 and a set of variable number tandem repeats. Clin Microbiol Infect 14, 644-652.

Pedersen, L. N., Herrmann, B. \& Møller, J. K. (2009). Typing Chlamydia trachomatis: from egg yolk to nanotechnology. FEMS Immunol Med Microbiol 55, 120-130.

Persson, K. \& Osser, S. (1993). Lack of evidence of a relationship between genital symptoms, cervicitis and salpingitis and different serovars of Chlamydia trachomatis. Eur J Clin Microbiol Infect Dis 12, 195-199.

Petrovay, F., Balla, E., Németh, I. \& Gönczöl, E. (2009). Genotyping of Chlamydia trachomatis from the endocervical specimens of highrisk women in Hungary. J Med Microbiol 58, 760-764.

Quint, K., Porras, C., Safaeian, M., González, P., Hildesheim, A., Quint, W., Van Doorn, L. J., Silva, S., Melchers, W. \& other authors (2007). Evaluation of a novel PCR-based assay for detection and identification of Chlamydia trachomatis serovars in cervical specimens. J Clin Microbiol 45, 3986-3991.

Stephens, R. S., Sanchez-Pescador, R., Wagar, E. A., Inouye, C. \& Urdea, M. S. (1987). Diversity of Chlamydia trachomatis major outer membrane protein genes. J Bacteriol 169, 3879-3885.

Stothard, D. R., Boguslawski, G. \& Jones, R. B. (1998). Phylogenetic analysis of the Chlamydia trachomatis major outer membrane protein and examination of potential pathogenic determinants. Infect Immun 66, 3618-3625.

Sturm-Ramirez, K., Brumblay, H., Diop, K., Guèye-Ndiaye, A., Sankalé, J. L., Thior, I., N'Doye, I., Hsieh, C. C., Mboup, S. \& Kanki, P. J. (2000). Molecular epidemiology of genital Chlamydia trachomatis infection in high-risk women in Senegal, West Africa. J Clin Microbiol 38, 138-145.

Taheri Beni, B., Motamedi, H. \& Ardakani, M. R. (2010). Genotyping of the prevalent Chlamydia trachomatis strains involved in cervical infections in women in Ahvaz, Iran. J Med Microbiol 59, 1023-1028.

Van de Laar, M. J., Van Duynhoven, Y. T., Fennema, J. S., Ossewaarde, J. M., Van den Brule, A. J., Van Doornum, G. J., Coutinho, R. A. \& Van den Hoek, J. A. (1996). Differences in clinical manifestations of genital chlamydial infections related to serovars. Genitourin Med 72, 261-265.

Van Duynhoven, Y. T., Ossewaarde, J. M., Derksen-Nawrocki, R. P., Van der Meijden, W. I. \& Van de Laar, M. J. (1998). Chlamydia trachomatis genotypes: correlation with clinical manifestations of infection and patients' characteristics. Clin Infect Dis 26, 314-322.

Wang, S. P., Kuo, C. C. \& Grayston, J. T. (1973). A simplified method for immunological typing of trachoma-inclusion conjunctivitislymphogranuloma venereum organisms. Infect Immun 7, 356-360.

WHO (2001). Global Prevalence and Incidence of Selected Curable Sexually Transmitted Infections: Overview and estimates, pp. 10-14. Geneva: World Health Organization. www.who.int/hiv/pub/sti/who_ hiv_aids_2001.02.pdf

Yuan, Y., Zhang, Y. X., Watkins, N. G. \& Caldwell, H. D. (1989). Nucleotide and deduced amino acid sequences for the four variable domains of the major outer membrane proteins of the 15 Chlamydia trachomatis serovars. Infect Immun 57, 1040-1049. 